\title{
Spermatogenic Waves and Expression of AR and ERs in Germ Cells of Podarcis sicula
}

\author{
Mariailaria Verderame, ${ }^{1}$ Francesco Angelini, ${ }^{2}$ and Ermelinda Limatola ${ }^{1}$ \\ ${ }^{1}$ Department of Biology, University "Federico II" of Naples, Via Mezzocannone 8, 80134 Naples, Italy \\ ${ }^{2}$ Department of Biology, University "Federico II" of Naples, Via Cinthia, 80126 Naples, Italy
}

Correspondence should be addressed to Mariailaria Verderame; ilaria.verderame@unina.it

Received 29 August 2014; Accepted 6 November 2014; Published 23 November 2014

Academic Editor: Greg Demas

Copyright (C) 2014 Mariailaria Verderame et al. This is an open access article distributed under the Creative Commons Attribution License, which permits unrestricted use, distribution, and reproduction in any medium, provided the original work is properly cited.

\begin{abstract}
Androgens are considered the main hormones that regulate spermatogenesis, but a lot of evidence confers to estrogen a key role in this process. In the testis of the seasonal breeder lizard Podarcis sicula we analyzed by means of in situ hybridization the expression of the androgen receptor (AR) and of the two types, $\alpha$ and $\beta$, of the estrogen receptors (ERs) throughout the three periods of the annual cycle: mating (spring-early summer), postmating-refractory (late summer), and autumnal recrudescence. The results show that during the mating period AR and ERs are expressed in all germ cells present in the tubules from spermatogonia to spermatozoa. During the postmating-refractory period, when only spermatogonia are present in the tubules, almost all express ERs and very few AR mRNA. During the autumnal recrudescence the localization of AR and ERs is the same of the mating period except for the population of the primary spermatocytes. The expression of the investigated receptors is peculiar in these cells that are positive in the middle-late pachytene stage of the meiotic prophase and negative in preleptotene. A possible functional role of the observed differences during spermatogenesis and in the spermatozoa is also discussed.
\end{abstract}

\section{Introduction}

The androgen receptor (AR) and the two types of the estrogen receptors $(\mathrm{ER} \alpha$ and $\mathrm{ER} \beta)$ are members of the large superfamily of ligand-activated hormone receptors and act as ligand-inducible transcription factors $[1,2]$. Even though the expression of these three types of steroid receptors is reported in the testis of many mammalian species [3-9] their role is not well defined in male reproductive system and even if the male tract is an example where these receptors are expressed $[6,10]$ the reports about their localization are controversial [11].

More than 20 years ago in mammals, it was thought that AR was not expressed in male germ cells $[12,13]$, but later some evidence showed the expression of AR in spermatogonia, spermatocytes, elongated spermatids, and spermatozoa [14-16]. Regarding ERs, in all mouse germ cells only $\operatorname{ER} \beta$ is detected $[6,17]$; in the human some authors reported a complete absence of $\operatorname{ER} \alpha[18,19]$ while some others suggested its expression in primary spermatocytes and spermatids and in the ejaculated sperm [4, 20-22].
Among lower vertebrates, in the amphibians that show a cystic structure of the testis, the estrogen guarantees in Rana esculenta the progression of spermatogenesis and release of spermatozoa [23-25] and in Triturus marmoratus immunoreactive $\mathrm{AR}, \mathrm{ER} \alpha$, and $\mathrm{ER} \beta$ are reported in the germ cells [26]. In the tubular testis of rooster, only spermatogonia and early spermatocytes express ER $\beta$ but do not express ER $\alpha$ [27]. In Trachemys scripta among reptiles, ER $\beta$ immunoreactivity was found in spermatogonia [28]; in Chelonia mydas AR and ER $\beta$ were found in germ cell at stage IV while $\mathrm{ER} \alpha$ was observed only in the somatic cells [29]; in the snake Zaocys dhumnades AR and ER were reported in spermatids [30]. No data are available in reptiles about the localization of the transcripts of both androgen and estrogen receptors in the seminiferous epithelium.

Our experimental model is the lizard Podarcis sicula that, as many reptiles living in regions with marked circannual climatic variations, is a seasonal breeding species and its spermatogenic cycle is dependent on temperature and 
photoperiod [31]. Furthermore in this lizard the testis shows a tubular structure like mammals.

In Podarcis the mating period occurs in spring when the intense spermatogenic activity in the testis gives rise to a lot of spermatozoa sent to the rete testis and epididymal channel to be then ejaculated. In the early summer the spermatogenesis is over and Podarcis enters in the status considered a condition of physiological hypophysectomy named refractoriness during which the lizards are unresponsive to endogenous or exogenous hormones [32]. In the fall Podarcis shows a spermatogenic recrudescence considered the reminiscence of two reproductive events in the ancestor of this lizard living in the milder environments [31]. Furthermore, in this lizard are known some data about the expression of androgen and estrogen receptors in the whole testis [33-35] and the pattern of sexual steroids hormones, that is, during the reproductive cycle [31].

The aim of this research was to obtain in Podarcis an overview on the expression of $\mathrm{AR}, \mathrm{ER} \alpha$, and $\operatorname{ER} \beta$ in the seminiferous epithelium throughout the annual cycle. We will also try to assign a possible functional role to the difference in the ability of germ cells to transcribe the receptors during their progression in the spermatogenic events. For this purpose we analyzed the expression of these receptors in the testis by means of in situ hybridization with homologous probes already cloned by us [36-38].

\section{Material and Methods}

2.1. Animals. For this study were used males of lizard Podarcis sicula whose spermatogenic cycle in natural or experimental conditions is well known [31].

Adult males (about $7.5-8 \mathrm{~cm}$ snout-vent) of lizard Podarcis sicula were captured near Naples (Italy) during the mating period (spring-early summer) $[n=10]$, the postmatingrefractory period (late summer) $[n=10]$, and the recrudescence (fall) $[n=10]$. They were kept in terraria at natural temperature and photoperiod and fed ad libitum with larvae of Tenebrio molitor. The animals were killed by decapitation after anaesthesia on ice and the testes, immediately excised, were processed for histological and biomolecular analyses. Authorization to capture the animals for experimental treatments was granted by the Italian Ministry of the Environment (auth. SCN/2D/2000/9213).

2.2. Histology. Both testes of each animal were fixed in Bouin's fluid [39], alcohol-dehydrated, and paraffin-embedded. Sections $7 \mu \mathrm{m}$ in thickness were obtained with Reichert-Jung 2030 microtome. Some histological sections were stained with Mallory's trichrome modified by Galgano [39]; other sections were processed by in situ hybridization (ISH). The results were examined at Nikon-MicroPhot-Fxa microscope.

2.3. In Situ Hybridization (ISH). The ISH was performed by using homologous digoxigenin (DIG) labelled cDNA fragments of $\mathrm{ER} \alpha, \mathrm{ER} \beta$, or $\mathrm{AR}$, as already reported for the liver and epididymis $[37,38,40]$. Briefly, the dewaxed sections were treated with proteinase $\mathrm{K}(10 \mu \mathrm{g} / \mathrm{mL})$ at $50^{\circ} \mathrm{C}$ for $10 \mathrm{~min}$. The probes were used at a concentration of $80 \mathrm{ng} / 100 \mu \mathrm{L}$ in hybridization buffer overnight at $50^{\circ} \mathrm{C}$ in a moist chamber. The slides were washed with formamide $50 \%$ and SSC $2 \mathrm{x}$ for $30 \mathrm{~min}$, formamide $50 \%$ and SSC $1 \mathrm{x}$ for $30 \mathrm{~min}$, and formamide $50 \%$ and SSC $0.5 \mathrm{x}$ for $15 \mathrm{~min}$, washed in $2 \mathrm{x}$ SSC for $3 \mathrm{~min}$ and in NTP (Tris- $\mathrm{HCl} 0.1 \mathrm{M} \mathrm{pH} \mathrm{7.5;} \mathrm{NaCl}$ $0.15 \mathrm{M}$ ), and then incubated in $2 \%$ blocking solution (Roche Diagnostics, Mannheim, Germany) in maleic acid buffer for 1h. The sections were kept overnight at $4^{\circ} \mathrm{C}$ with alkaline phosphatase-conjugated sheep anti-DIG antibody (Roche Diagnostics) $(1: 2500)$ in blocking solution and rinsed in NTP buffer for $30 \mathrm{~min}$ and in NTM buffer (Tris-HCl $100 \mathrm{mM}$ $\mathrm{pH}$ 9.5, $\mathrm{MgCl} 50 \mathrm{mM}, \mathrm{NaCl} 100 \mathrm{mM}$ ) for $30 \mathrm{~min}$. Finally, the sections were kept in the dark at room temperature in the colour detection substrate solution BCIP/NBT (nitroblue tetrazolium and 5-bromo-4-chloro- $3^{\prime}$-indolyphosphate, Roche) in NTM until appearance of the reaction.

Control sections were obtained by omitting incubation with the probes. Some other sections were pretreated with DNase to exclude cross-link with genomic DNA.

\section{Results}

3.1. Histology. In the males of lizard Podarcis sicula the reproductive annual cycle starts with the mating period lasting from spring to early summer, followed by the postreproductive-refractory period and by the autumnal recrudescence.

Although the structure of the testis during this cycle is known, a concise description of the histological features of the seminiferous tubules around the year is necessary for the evaluation of the results concerning the purpose of this research. In the mating period a great amount of sperms fills the lumen of the tubules where all stages of the spermatogenesis are detectable as spermatogonia (spg), primary spermatocytes (spcI), secondary spermatocytes (spcII), round and elongated spermatids (spd), and spermatozoa $(\mathrm{spz})$ (Figure 1(a)). The spg are located on the basal membrane; above these, many spcI in different stages of the meiotic prophase from preleptotene, pachytene, diplotene until diakinesis are easily recognizable according to the aspect of the chromatin. The spcII are located upper and show a smaller diameter. Toward the lumen several round spermatids show the presence of the acrosomal bubble (Figures 1(b) and $1(c))$. Such organization of the seminiferous epithelium is not uniform on the whole surface of the tubule because the development of the germ cells from spc to spz proceeds in a spiral as reported in other reptiles and in mammals [41, 42].

At the end of mating period (late July) the spermatogenesis is over and the seminiferous epithelium gradually reduces in thickness up to only spg and Sertoli cells remain (Figure 2(a)). Sometimes few residual cells are still evident in the restricted lumen of the tubules. At this stage the refractoriness sets in.

In the fall the refractoriness slows down and the spermatogenesis resumes (autumnal recrudescence) until the production of few spermatozoa (Figure 3(a)) that are useless since the couplings do not occur in this period. 


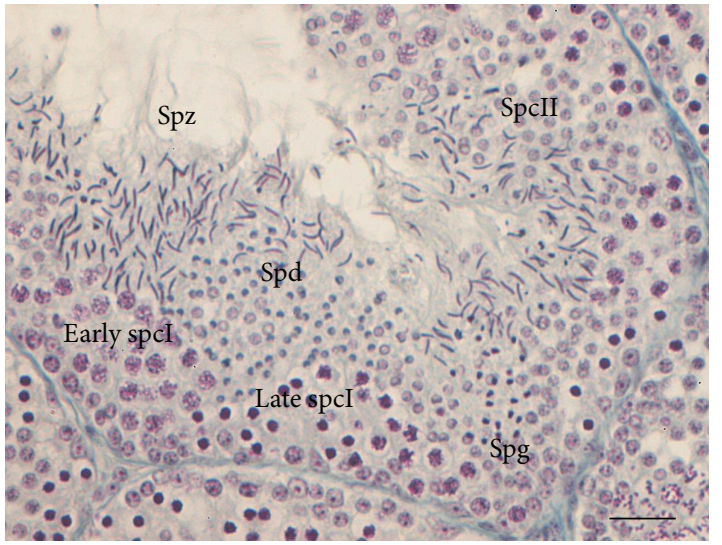

(a)

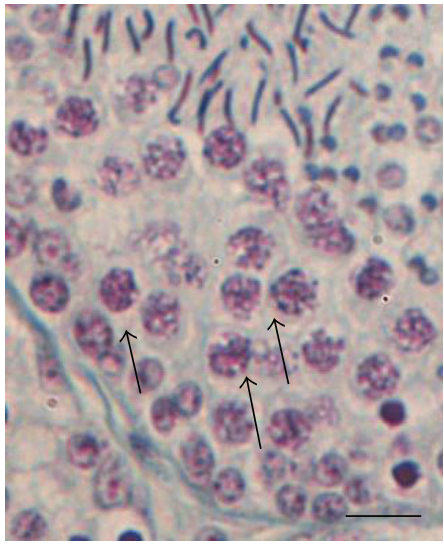

(b)

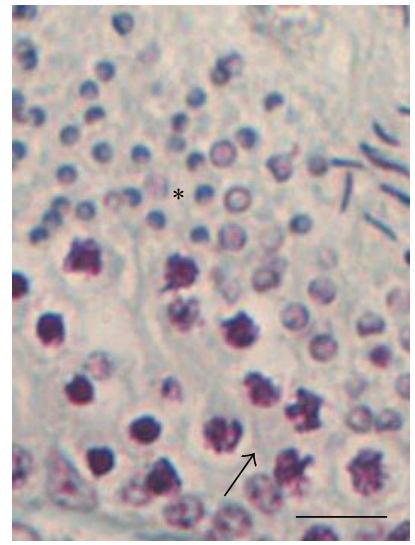

(c)

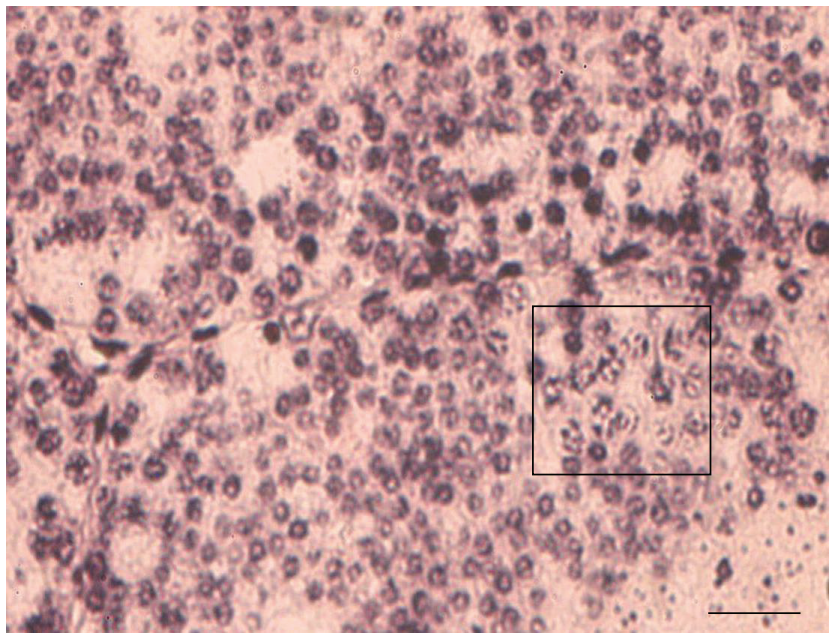

(d)

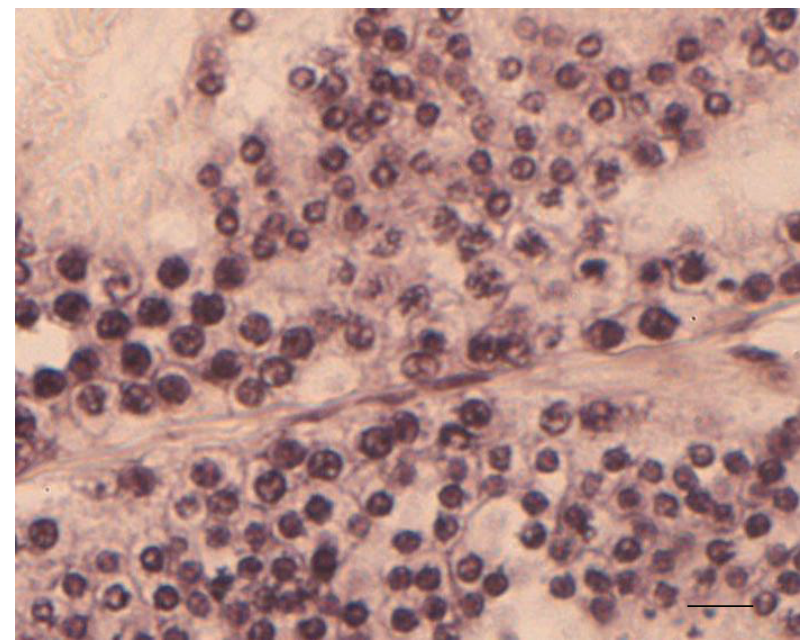

(f)

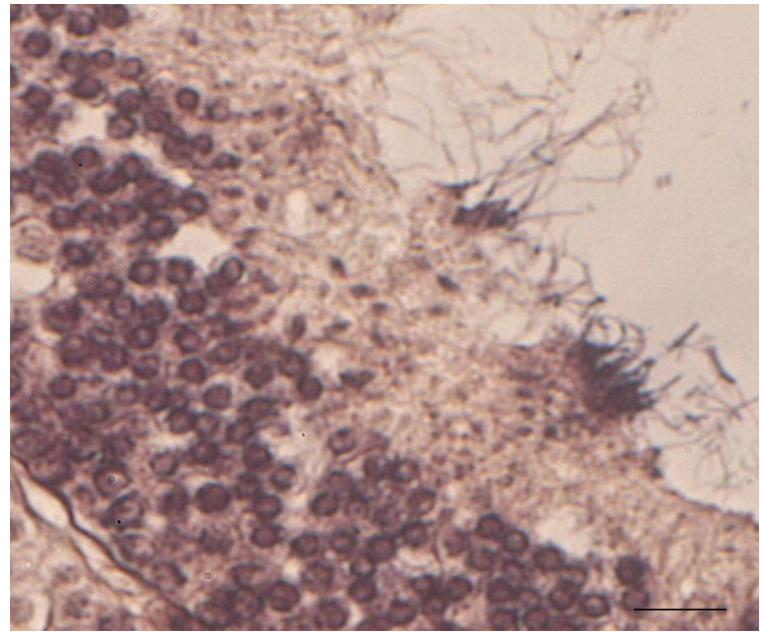

(e)

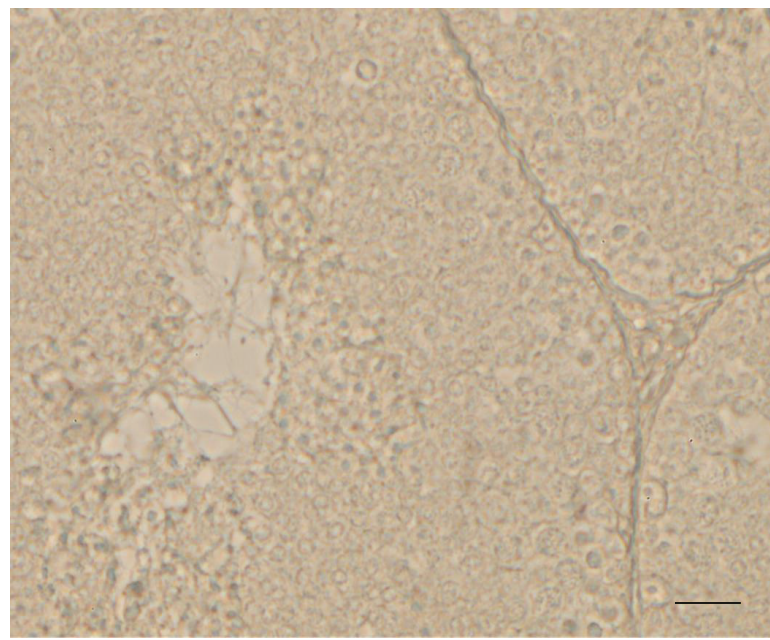

(g)

FIGURE 1: Histology and mRNA distribution of AR and ERs in the testis during the mating period. (a, b, c) Mallory's trichrome staining: (a) all stages of germ cells differentiation: spg, spcI, spcII, spd, and spz are evident in a seminiferous tubule; (b) spcI in preleptotene stage (arrows), the red nucleolus is still evident (magnification of (a)); (c) spcI in pachytene stage (arrows), note the condensation of chromatin to constitute chromosomes. The asterisk marks the round spermatids (magnification of (a)). (d, e, f) ISH with homologous probes: (d) expression of AR (the square indicates the spcI in pachytene stage); in (e) expression of ER $\alpha$; (f) expression of ER $\beta$; (g) ISH-negative control section by omitting the probes. The bar is $30 \mu \mathrm{m}$. 


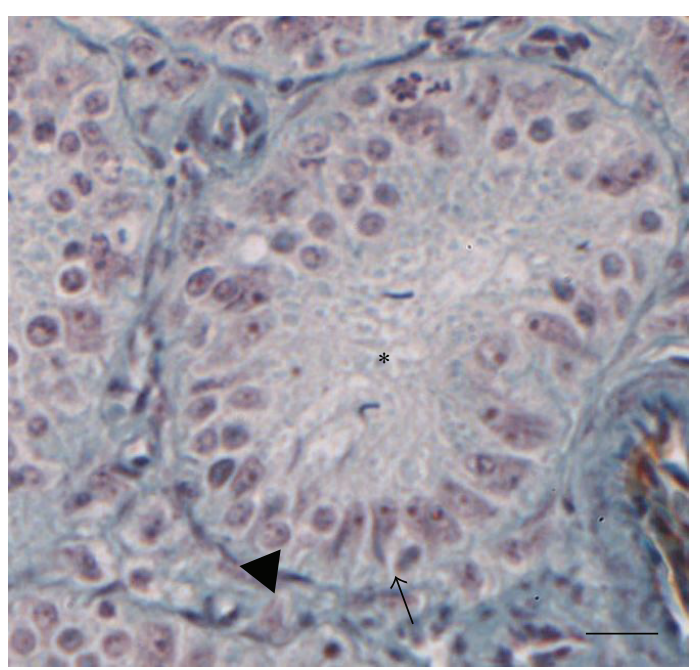

(a)

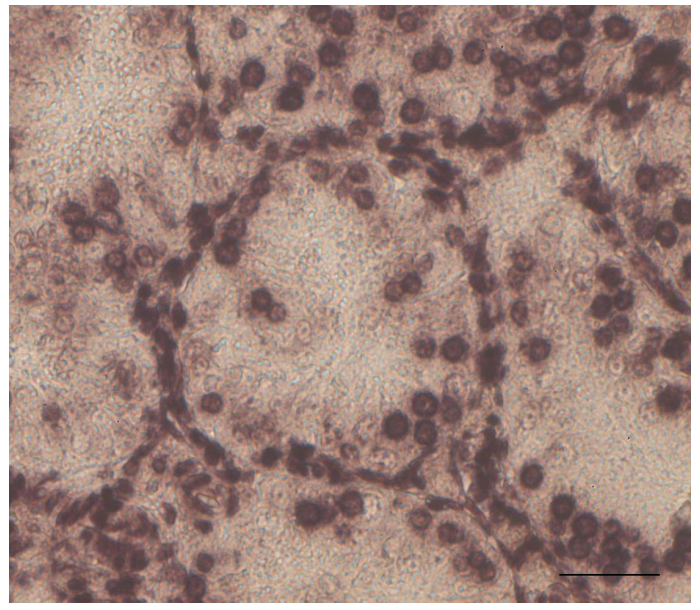

(c)

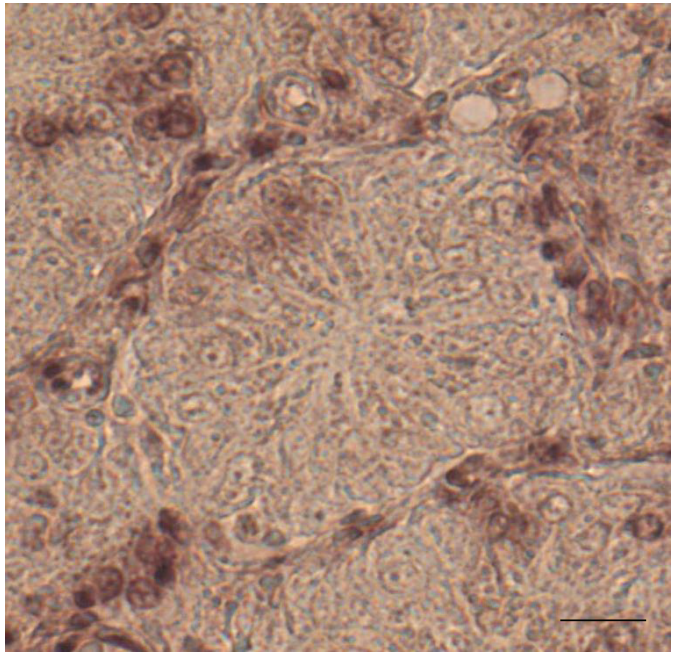

(b)

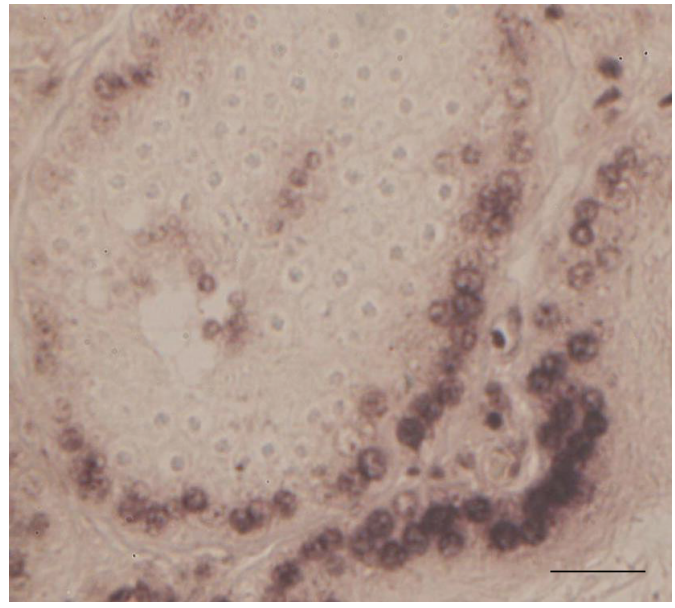

(d)

FIGURE 2: Histology and mRNA distribution of AR and ERs in the testis during the postmating-refractory period. (a) Mallory's trichrome staining: histological section of seminiferous tubules: note the restricted lumen $(*)$ and the seminiferous epithelium constituted essentially by spg (head of arrows) and Sertoli cells (arrows). (b, c, d) ISH with homologous probes: on the basis of the tubules almost all spg are negative for AR (b) and positive for $\operatorname{ER} \alpha$ (c) or $\operatorname{ER} \beta$ (d). The bar is $30 \mu \mathrm{m}$.

At the beginning of the new year spermatogenesis starts again to culminate in spring with the onset of a new mating period (data not shown).

3.2. In Situ Hybridization with ER $\alpha$, ER $\beta$, or AR Probes. In the seminiferous tubules during the mating period almost all the germinal cells, from spg to spz, are positive for AR (Figure 1(d)), ER $\alpha$ (Figure 1(e)), or ER $\beta$ (Figure 1(f)) mRNA. Occasionally few preleptotene spcI were negative.

In the postmating-refractory period the spg are poorly positive to AR mRNA (Figure 2(b)) but are strongly positive to $\mathrm{ER} \alpha$ (Figure 2(c)) or ER $\beta$ probes (Figure 2(d)).

In the months of the autumnal recrudescence AR (Figure 3(b)), ER $\alpha$ (Figure 3(c)), and ER $\beta$ (Figure 3(d)) were expressed in almost all spg, spcII, and spd as in the mating period, while a lot of spcI in preleptotene were negative and constitute a large circular ring between the spg and spcII
(Figures 3(b), 3(c), and 3(d)). The few spcI in pachytene stage, detectable in this area, were positive for the three receptors. No reaction was observed in the spermatozoa.

The responsiveness of the spermatozoa during the mating period and autumnal recrudescence was displayed in Figure 4.

The ISH performed on control sections by omitting the incubation with $\mathrm{AR}, \mathrm{ER} \alpha$, or $\mathrm{ER} \beta$ probes was negative in all the different stages of the reproductive cycle (for all we reported one picture, Figure 1(g)). The sections pretreated with DNAse showed the same features of the untreated ones (data not shown).

\section{Discussion}

Our research analyzed in parallel for the first time the expression of $\mathrm{AR}, \mathrm{ER} \alpha$, and $\mathrm{ER} \beta$ by means of in situ hybridization 


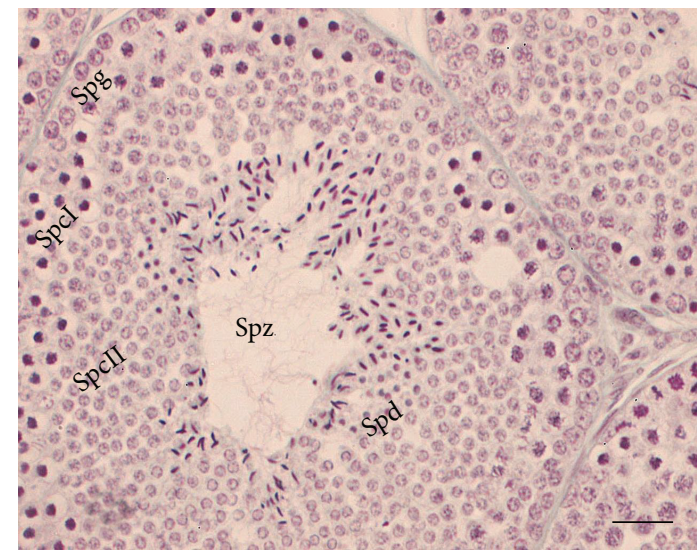

(a)

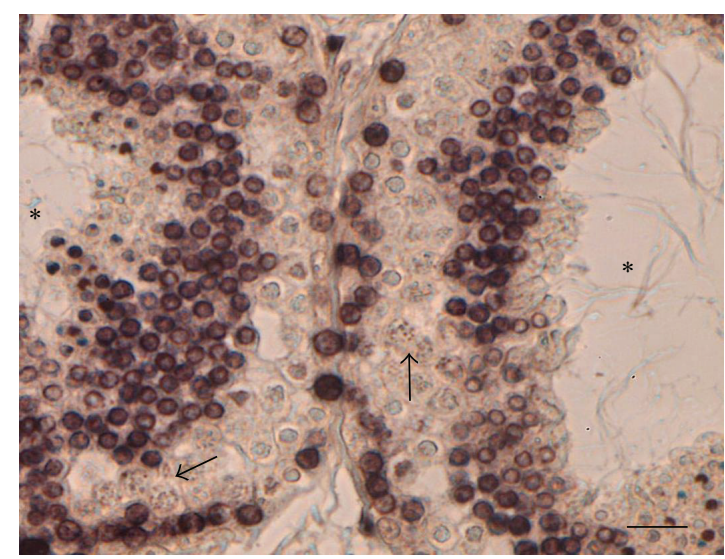

(c)

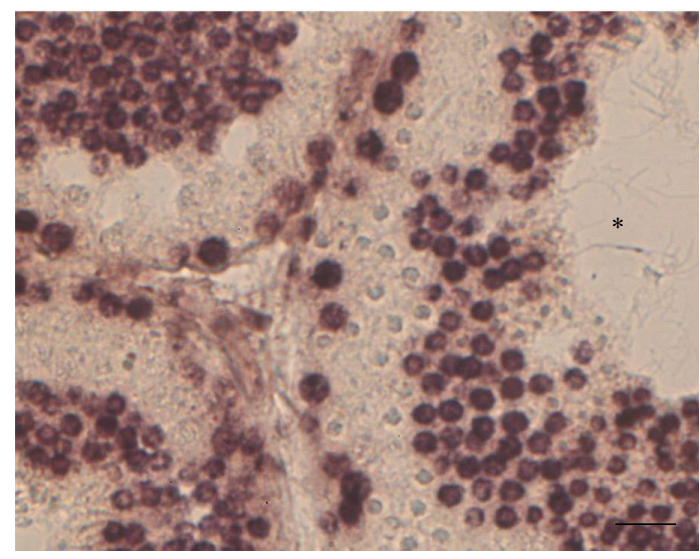

(b)

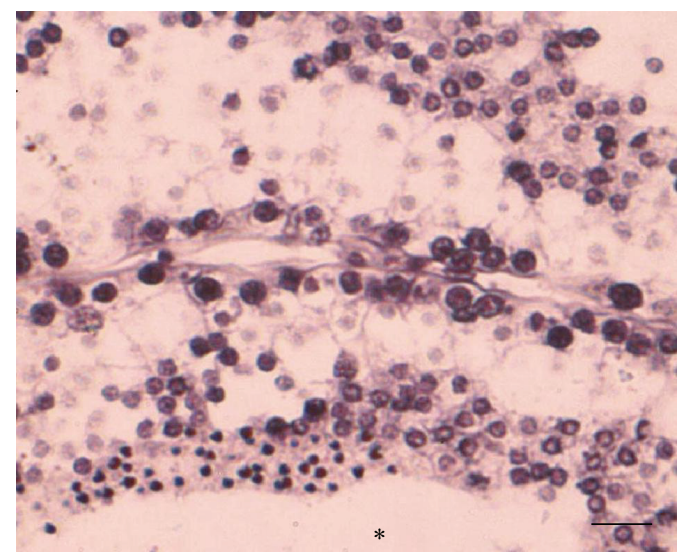

(d)

FIGURE 3: Histology and mRNA distribution of AR and ERs in the testis during the autumnal recrudescence. (a) Mallory's trichrome staining: all stages of germ cells differentiation from spg to spz are evident in the seminiferous epithelium as in the mating period. (b, $\mathrm{c}, \mathrm{d}$ ) ISH with homologous probes: intense positivity to AR (b), ER $\alpha$ (c), or ER $\beta$ (d) probes of the spg, on the basis of the tubules, and of spcII near the lumen $(*)$; the spcI in pre-leptotene constitute a large negative circular ring where only few pachitene cells (arrows) are slightly positive. The bar is $30 \mu \mathrm{m}$.

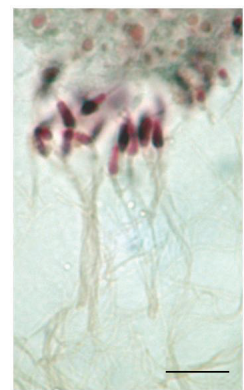

(a)

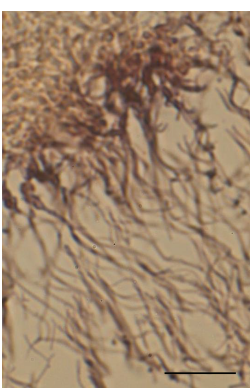

(b)

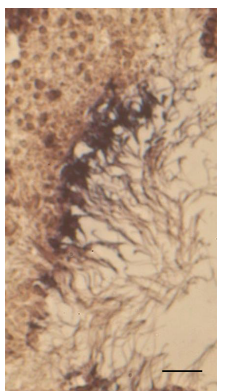

(c)

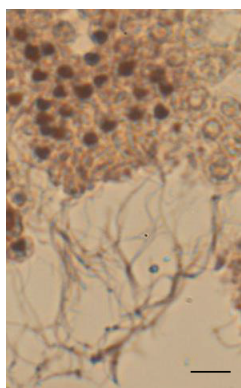

(d)

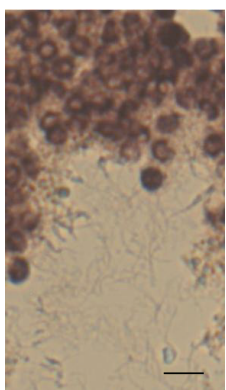

(e)

FIGURE 4: Spermatozoa in the seminiferous epithelium. (a) Mallory's trichrome stained section. (b, c, d, e) ISH with homologous probes: spermatozoa positive to $\operatorname{AR}(b), E R \alpha,(c)$ and $\operatorname{ER} \beta$ (d) in the mating period; spermatozoa negative in the autumnal recrudescence (e) (one for all is depicted $\mathrm{ER} \alpha$ ). The bar is $30 \mu \mathrm{m}$. 
with homologous probes in the seminiferous epithelium of the lizard Podarcis sicula during the reproductive annual cycle. The present data indicate that the arrangement of the reproductive events in a seasonal breeding species makes it easier to correlate the seasonal histological changes with biomolecular approaches. In particular the results show that all male differentiating germ cells are able to express androgen and/or estrogen receptors and suggest that the almost constant presence of AR and ERs mRNA often observed may be related to the continuous hormonal occurrence throughout the cycle even if at different concentration. In fact in Podarcis the plasma level of testosterone (T) reaches the maximum during the mating period and falls down in the postmating period while its endotesticular profile shows always significant levels. The plasma levels of estradiol 17- $\beta$ $\left(E_{2}\right)$ are instead consistent with endotesticular titers, rising at the end of the mating and remaining discrete until the autumnal recrudescence [31, 43].

Furthermore our findings show that in Podarcis during the mating period the expression of the $\mathrm{AR}, \mathrm{ER} \alpha$, and $\mathrm{ER} \beta$ mRNA occurs at the same time in spg, spcI, spcII, spd, and spz. The significance of the simultaneous expression of the androgen and estrogen receptors during the spermatogenesis has yet to be clarified in Podarcis as in other vertebrates, but some data showed in mammals a possible interplay between them. In hamster multiple consensus sequences in the promoter region of $\mathrm{AR}$ recognize $\mathrm{ER}$ or $\mathrm{AR}$ itself as transcription factors [44]. In mouse mammary cells the interaction $\mathrm{E}_{2} / \mathrm{ER}$ inhibits transcriptional activity of DHT/AR complex, in vitro [45]. Physical AR-ER $\alpha$ interactions, in mammalian twohybrid systems, arise between the C-terminal ER $\alpha$ ligandbinding domain and the $\mathrm{N}$-terminal AR transactivational domain or with the full-length of $\mathrm{AR}$, while $\mathrm{ER} \beta$ does not interact with AR [46]. Moreover $\mathrm{E}_{2}$ itself can bind weakly to the AR $[47,48]$ and can activate an androgen-responsive element $[49,50]$. In addition, the two types of the estrogen receptors may form homodimers or heterodimers which have different affinities with the estrogen-responsive element [51] and, in the uterine cells, ER $\beta$ may negatively regulate $\mathrm{ER} \alpha$ [52].

In Podarcis at the end of the mating period, almost exclusively spg and Seroli cells remain in the seminiferous tubules and very few spg express AR-mRNA while most of them are positive for ERs. In this period the plasma levels of $\mathrm{E}_{2}$ are at zenith in this species [31] and in vitro $\mathrm{E}_{2}$ autoregulates ER-mRNA and downregulates AR-mRNA [34]. Therefore it is possible to hypothesize that the expression of $\mathrm{AR}$ in some spermatogonia may distinguish ones that will come in meiosis.

In vertebrates the spermatogenesis is guaranteed by a series of mitotic and meiotic waves that in Podarcis takes place twice in a year, the first in spring and the second in the fall. In these two spermatogenic events we recorded some differences in the expression of the investigated receptors in particular at level of spz and on the population of spcI. Concerning the spermatozoa we found the expression of $\mathrm{AR}, \mathrm{ER} \alpha$, and $\mathrm{ER} \beta$ in the mating period unlike in the fall. In some mammals $[53,54]$ the terminal differentiation of spermatids and their release from the seminiferous epithelium are AR dependent and in AR knockout mice [55] the development of spermatozoa is impaired. On the other hand the estrogens, through their receptors, guarantee sperm function and release and prevent spermatid death [14, 24, 25, 56-59]. Since in Podarcis the spz produced during the autumnal recrudescence do not pass in the epididymis [31,37], the expression of the three receptors in the mating period may characterize the spz that will be ejaculated.

The other difference in the two annual spermatogenic events of Podarcis concerns the population of spcI. The large amount of spcI in middle or late pachytene stage, present in the mating period, expresses mRNA for all the three receptors whereas the few preleptotene spcI are negative. On the contrary, the amount of spcI in pachytene stage is much smaller during the autumnal recrudescence and remains positive to the AR or ERs probes while the large amount of preleptotene remains negative. Taken together these findings suggest that the spcI cannot express the receptors at the early stage of meiotic prophase and acquire such ability later. In reptiles the pachytene is highly synthetic and represents the longest stage of prophase as in mammals [41, 42] and the conversion from middle to late pachytene spermatocytes is critical for the maturation of rat germ cells in vitro [60].

In synthesis in Podarcis during the mating period the great amount of spcI expressing the three receptors may be likely due to the high frequency in the succession of spermatogenic waves in this period. In the same way the presence in the autumnal recrudescence of many negative spcI and of very few positive pachytene cells may be consequence of a lower frequency of the spermatogenic waves in this period. Furthermore the almost complete lack of expression observed almost always in preleptotene during the autumnal recrudescence and only occasionally during the mating period may represent a sort of interwave resting stage.

Therefore in Podarcis, while the timing of the reproductive cycle is given by the seasonal changes as it is known, the speed and frequency of the spermatogenic waves in the mating period or in the autumnal recrudescence may be set by the amount of spcI expressing AR, ER $\alpha$, and ER $\beta$-mRNA.

It would be interesting to check if the role ascribed to the spcI in Podarcis can be verified in other reptiles or in higher vertebrates showing two or more mating periods in the year.
Abbreviations
spg: Spermatogonia
spcI: Primary spermatocytes
spcII: Secondary spermatocytes
spd: Spermatids
spz: Spermatozoa
AR: Androgen receptor
$\mathrm{ER} \alpha$ : Estrogen receptor $\alpha$
$\mathrm{ER} \beta$ : Estrogen receptor $\beta$
$\mathrm{E}_{2}$ : Estradiol 17- $\beta$
$\mathrm{T}$ : Testosterone.

\section{Conflict of Interests}

The authors declare that there is no conflict of interests regarding the publication of this paper. 


\section{Acknowledgment}

The authors are grateful to Dr. Susan Campbell for linguistic revision of the paper.

\section{References}

[1] M. Beato, "Gene regulation by steroid hormones," Cell, vol. 56, no. 3, pp. 335-344, 1989.

[2] D. J. Mangelsdorf and R. M. Evans, "The RXR heterodimers and orphan receptors," Cell, vol. 83, no. 6, pp. 841-850, 1995.

[3] B. Bilińska, B. Schmalz-Fraçzek, J. Sadowska, and S. Carreau, "Localization of cytochrome P450, aromatase and estrogen receptors $\alpha$ and $\beta$ in testicular cells-an immunohistochemical study of the bank vole," Acta Histochemica, vol. 102, no. 2, pp. 167-181, 2000.

[4] V. Pentikäinen, K. Erkkilä, L. Suomalainen, M. Parvinen, and L. Dunkel, "Estradiol acts as a germ cell survival factor in the human testis in vitro," Journal of Clinical Endocrinology and Metabolism, vol. 85, no. 5, pp. 2057-2067, 2000.

[5] L. O'Donnell, K. M. Robertson, M. E. Jones, and E. R. Simpson, "Estrogen and spermatogenesis," Endocrine Reviews, vol. 22, no. 3, pp. 289-318, 2001.

[6] Q. Zhou, R. Nie, G. S. Prins, P. T. K. Saunders, B. S. Katzenellenbogen, and R. A. Hess, "Localization of androgen and estrogen receptors in adult male mouse reproductive tract," Journal of Andrology, vol. 23, no. 6, pp. 870-881, 2002.

[7] S. Carreau and R. A. Hess, "Oestrogens and spermatogenesis," Philosophical Transactions of the Royal Society B: Biological Sciences, vol. 365, no. 1546, pp. 1517-1535, 2010.

[8] M.-Y. Tsai, S.-D. Yeh, R.-S. Wang et al., "Differential effects of spermatogenesis and fertility in mice lacking androgen receptor in individual testis cells," Proceedings of the National Academy of Sciences of the United States of America, vol. 103, no. 50, pp. 18975-18980, 2006.

[9] G. Verhoeven, A. Willems, E. Denolet, J. V. Swinnen, and K. de Gendt, "Androgens and spermatogenesis: lessons from transgenic mouse models," Philosophical Transactions of the Royal Society B: Biological Sciences, vol. 365, no. 1546, pp. 15371556, 2010.

[10] R. Nie, Q. Zhou, E. Jassim, P. T. K. Saunders, and R. A. Hess, "Differential expression of estrogen receptors $\alpha$ and $\beta$ in the reproductive tracts of adult male dogs and cats," Biology of Reproduction, vol. 66, no. 4, pp. 1161-1168, 2002.

[11] R. A. Hess and K. Carnes, "The role of estrogen in testis and the male reproductive tract: a review and species comparison," Animal Reproduction, vol. 1, no. 1, pp. 5-30, 2004.

[12] M. Sar, D. B. Lubahn, F. S. French, and E. M. Wilson, "Immunohistochemical localization of the androgen receptor in rat and human tissues," Endocrinology, vol. 127, no. 6, pp. 3180-3186, 1990.

[13] J. A. Grootegoed, M. J. Peters, E. Mulder, F. F. G. Rommerts, and H. J. van der Molen, "Absence of a nuclear androgen receptor in isolated germinal cells of rat testis," Molecular and Cellular Endocrinology, vol. 9, no. 2, pp. 159-167, 1977.

[14] V. Rago, S. Aquila, R. Panza, and A. Carpino, "Cytochrome P450arom, androgen and estrogen receptors in pig sperm," Reproductive Biology and Endocrinology, vol. 5, article 23, 2007.

[15] X. Zhou, A. Kudo, H. Kawakami, and H. Hirano, "Immunohistochemical localization of androgen receptor in mouse testicular germ cells during fetal and postnatal development," Anatomical Record, vol. 245, no. 3, pp. 509-518, 1996.
[16] N. Kimura, A. Mizokami, T. Oonuma, H. Sasano, and H. Nagura, "Immunocytochemical localization of androgen receptor with polyclonal antibody in paraffin-embedded human tissues," Journal of Histochemistry \& Cytochemistry, vol. 41, no. 5, pp. 671-678, 1993.

[17] T. F. G. Lucas, E. R. Siu, C. A. Esteves et al., "17Beta-estradiol induces the translocation of the estrogen receptors ESR1 and ESR2 to the cell membrane, MAPK3/1 phosphorylation and proliferation of cultured immature rat sertoli cells," Biology of Reproduction, vol. 78, no. 1, pp. 101-114, 2008.

[18] J. E. Sierens, S. F. Sneddon, F. Collins, M. R. Millar, and P. T. K. Saunders, "Estrogens in testis biology," Annals of the New York Academy of Sciences, vol. 1061, pp. 65-76, 2005.

[19] G. Pelletier and M. El-Alfy, "Immunocytochemical localization of estrogen receptors $\alpha$ and $\beta$ in the human reproductive organs," The Journal of Clinical Endocrinology \& Metabolism, vol. 85, no. 12, pp. 4835-4840, 2000.

[20] S. Aquila, D. Sisci, M. Gentile et al., "Estrogen receptor (ER) $\alpha$ and $\operatorname{ER} \beta$ are both expressed in human ejaculated spermatozoa: evidence of their direct interaction with phosphatidylinositol-3$\mathrm{OH}$ kinase/Akt pathway," Journal of Clinical Endocrinology and Metabolism, vol. 89, no. 3, pp. 1443-1451, 2004.

[21] S. Lambard, I. Galeraud-Denis, P. T. K. Saunders, and S. Carreau, "Human immature germ cells and ejaculated spermatozoa contain aromatase and oestrogen receptors," Journal of Molecular Endocrinology, vol. 32, no. 1, pp. 279-289, 2004.

[22] T. J. Durkee, M. Mueller, M. Zinaman, B. Cowan, and S. L. Hendrix, "Identification of estrogen receptor protein and messenger ribonucleic acid in human spermatozoa," American Journal of Obstetrics and Gynecology, vol. 178, no. 6, pp. 12881297, 1998.

[23] R. Pierantoni, G. Cobellis, R. Meccariello et al., "Testicular gonadotropin-releasing hormone activity, progression of spermatogenesis, and sperm transport in vertebrates," Annals of the New York Academy of Sciences, vol. 1163, pp. 279-291, 2009.

[24] G. Cobellis, R. Pierantoni, S. Minucci, R. Pernas-Alonso, R. Meccariello, and S. Fasano, "c-fos Activity in Rana esculenta testis: seasonal and estradiol-induced changes," Endocrinology, vol. 140, no. 7, pp. 3238-3244, 1999.

[25] G. Cobellis, G. Cacciola, T. Chioccarelli et al., "Estrogen regulation of the male reproductive tract in the frog, Rana esculenta: a role in Fra-1 activation in peritubular myoid cells and in sperm release," General and Comparative Endocrinology, vol. 155, no. 3, pp. 838-846, 2008.

[26] M. I. Arenas, M. Royuela, M. V. T. Lobo, J. M. Alfaro, B. Fraile, and R. Paniagua, "Androgen receptor (AR), estrogen receptoralpha $(\mathrm{ER}-\alpha)$ and estrogen receptor-beta $(\mathrm{ER}-\beta)$ expression in the testis of the newt, Triturus marmoratus marmoratus during the annual cycle," Journal of Anatomy, vol. 199, no. 4, pp. 465472, 2001.

[27] A. G. Oliveira, R. A. P. Dornas, G. A. B. Mahecha, and C. A. Oliveira, "Occurrence and cellular distribution of estrogen receptors $\mathrm{ER} \alpha$ and $\mathrm{ER} \beta$ in the testis and epididymal region of roosters," General and Comparative Endocrinology, vol. 170, no. 3, pp. 597-603, 2011.

[28] D. H. Gist, S. Bradshaw, C. M. K. Morrow, J. D. Congdon, and R. A. Hess, "Estrogen response system in the reproductive tract of the male turtle: an immunocytochemical study," General and Comparative Endocrinology, vol. 151, no. 1, pp. 27-33, 2007.

[29] S. Otsuka, M. Suzuki, N. Kamezaki et al., "Growth-related changes in histology and immunolocalization of steroid hormone receptors in gonads of the immature male green turtle (Chelonia mydas)," Journal of Experimental Zoology Part A: 
Ecological Genetics and Physiology, vol. 309, no. 3, pp. 166-174, 2008.

[30] G. Liang, Q. Q. Liu, H. H. Yu, and Q. X. Wang, "Histological and immunocytochemical study of deferens ducts in the Chinese rat snake (Zaocys dhumnades)," Dongwuxue Yanjiu, vol. 32, no. 6, pp. 663-669, 2011.

[31] F. Angelini and V. Botte, "Spermatogenesis in reptiles, dynamic and regulatory aspect," in Sex Origin and Evolution, R. Dallai, Ed., pp. 211-230, Mucchi Selected Symposia and Monographs UZI, Modena, Italy, 1992.

[32] P. Licht, "Environmental control of annual testicular cycles in the lizard Anolis carolinensis. II. Seasonal variations in the effects of photoperiod and temperature on testicular recrudescence," Journal of Experimental Zoology, vol. 166, no. 2, pp. 243253, 1967.

[33] M. Paolucci and M. M. di Fiore, "Putative steroid-binding receptors and nonreceptor components and testicular activity in the lizard Podarcis sicula sicula," Journal of Reproduction and Fertility, vol. 96, no. 2, pp. 471-481, 1992.

[34] A. Cardone, F. Angelini, and B. Varriale, "Autoregulation of estrogen and androgen receptor mRNAs and downregulation of androgen receptor mRNA by estrogen in primary cultures of lizard testis cells," General and Comparative Endocrinology, vol. 110, no. 3, pp. 227-236, 1998.

[35] P. Chieffi and B. Varriale, "Estrogen receptor $\beta$ localization in the lizard (Podarcis s. sicula) testis," Zygote, vol. 12, no. 1, pp. 3942, 2004.

[36] M. Verderame and E. Limatola, "Molecular identification of estrogen receptors (ER $\alpha$ and $E R \beta)$ and their differential expression during VTG synthesis in the liver of lizard Podarcis sicula," General and Comparative Endocrinology, vol. 168, no. 2, pp. 231238, 2010.

[37] M. Verderame, F. Angelini, and E. Limatola, "Expression of estrogen receptor alpha switches off secretory activity in the epididymal channel of the lizard Podarcis sicula," Molecular Reproduction and Development, vol. 79, no. 2, pp. 107-117, 2012.

[38] M. Verderame, "The involvement of the androgen receptor in the secretion of the epididymal corpus in the lizard Podarcis sicula," International Journal of Zoology, vol. 2014, Article ID 457830, 6 pages, 2014.

[39] A. Mazzi, Manuale di tecniche istologiche e istochimiche, Piccin, Padua, Italy, 1977.

[40] M. Verderame, M. Prisco, P. Andreuccetti, F. Aniello, and E. Limatola, "Experimentally nonylphenol-polluted diet induces the expression of silent genes VTG and ER $\alpha$ in the liver of male lizard Podarcis sicula," Environmental Pollution, vol. 159, no. 5, pp. 1101-1107, 2011.

[41] V. Monesi, "Synthetic activities during spermatogenesis in the mouse. RNA and protein," Experimental Cell Research, vol. 39, no. 1, pp. 197-224, 1965.

[42] K. M. Gribbins, "Reptilian spermatogenesis: a histological and ultrastructural perspective," Spermatogenesis, vol. 1, no. 3, pp. 250-269, 2011.

[43] S. Andò, G. Ciarcia, M. L. Panno et al., "Sex steroids levels in the plasma and testis during the reproductive cycle of lizard Podarcis s. sicula raf," General and Comparative Endocrinology, vol. 85, no. 1, pp. 1-7, 1992.

[44] B. Varriale and T. Esposito, "The hamster androgen receptor promoter: a molecular analysis," Journal of Steroid Biochemistry and Molecular Biology, vol. 94, no. 1-3, pp. 103-110, 2005.

[45] M. V. Kumar, M. E. Leo, and D. J. Tindall, "Modulation of androgen receptor transcriptional activity by the estrogen receptor," Journal of Andrology, vol. 15, no. 6, pp. 534-542, 1994.
[46] V. Panet-Raymond, B. Gottlieb, L. K. Beitel, L. Pinsky, and M. A. Trifiro, "Interactions between androgen and estrogen receptors and the effects on their transactivational properties," Molecular and Cellular Endocrinology, vol. 167, no. 1-2, pp. 139-150, 2000.

[47] D. J. Tindall, F. S. French, and S. N. Nayfeh, "Estradiol-17 $\beta$ inhibition of androgen uptake, metabolism and binding in epididymis of adult male rats in vivo: a comparison with cyproterone acetate," Steroids, vol. 37, no. 3, pp. 257-268, 1981.

[48] L. R. Murthy, C. H. Chang, D. R. Rowley, P. T. Scardino, and D. J. Tindall, "Physicochemical characterization of the androgen receptor from hyperplastic human prostate," Prostate, vol. 5, no. 6, pp. 567-579, 1984.

[49] J. F. Glover and P. D. Darbre, "Multihormone regulation of MMTV-LTR in transfected T-47-D human breast cancer cells," Journal of Steroid Biochemistry, vol. 32, no. 3, pp. 357-363, 1989.

[50] S. Yeh, H. Miyamoto, H. Shima, and C. Chang, "From estrogen to androgen receptor: a new pathway for sex hormones in prostate," Proceedings of the National Academy of Sciences of the United States of America, vol. 95, no. 10, pp. 5527-5532, 1998.

[51] S. M. Cowley, S. Hoare, S. Mosselman, and M. G. Parker, "Estrogen receptors $\alpha$ and $\beta$ form heterodimers on DNA," The Journal of Biological Chemistry, vol. 272, no. 32, pp. 19858-19862, 1997.

[52] Z. Weihua, S. Saji, S. Mäkinen et al., "Estrogen receptor (ER) $\beta$, a modulator of ER $\alpha$ in the uterus," Proceedings of the National Academy of Sciences of the United States of America, vol. 97, no. 11, pp. 5936-5941, 2000.

[53] R. W. Holdcraft and R. E. Braun, "Androgen receptor function is required in Sertoli cells for the terminal differentiation of haploid spermatids," Development, vol. 131, no. 2, pp. 459-467, 2004.

[54] M. Kotula-Balak, A. Hejmej, M. Lydka, A. Cierpich, and B. Bilinska, "Detection of aromatase, androgen, and estrogen receptors in bank vole spermatozoa," Theriogenology, vol. 78, no. 2, pp. 385-392, 2012.

[55] C. Chang, Y.-T. Chen, S.-D. Yeh et al., "Infertility with defective spermatogenesis and hypotestosteronemia in male mice lacking the androgen receptor in Sertoli cells," Proceedings of the National Academy of Sciences of the United States of America, vol. 101, no. 18, pp. 6876-6881, 2004.

[56] K. M. Robertson, L. O’Donnell, M. E. E. Jones et al., "Impairment of spermatogenesis in mice lacking a functional aromatase (cyp 19) gene," Proceedings of the National Academy of Sciences of the United States of America, vol. 96, no. 14, pp. 7986-7991, 1999.

[57] S. Nilsson and J.-Å. Gustafsson, "Biological role of estrogen and estrogen receptors," Critical Reviews in Biochemistry and Molecular Biology, vol. 37, no. 1, pp. 1-28, 2002.

[58] G. Cacciola, T. Chioccarelli, L. Altucci et al., "Nuclear size as estrogen-responsive chromatin quality parameter of mouse spermatozoa," General and Comparative Endocrinology, vol. 193, pp. 201-209, 2013.

[59] S. Lambard, I. Galeraud-Denis, H. Bouraïma, S. Bourguiba, A. Chocat, and S. Carreau, "Expression of aromatase in human ejaculated spermatozoa: a putative marker of motility," Molecular Human Reproduction, vol. 9, no. 3, pp. 117-124, 2003.

[60] M.-H. Perrard, D. Hue, C. Staub, Y. Le Vern, D. Kerboeuf, and P. Durand, "Development of the meiotic step in testes of pubertal rats: comparison between the in vivo situation and under in vitro conditions," Molecular Reproduction and Development, vol. 65, no. 1, pp. 86-95, 2003. 

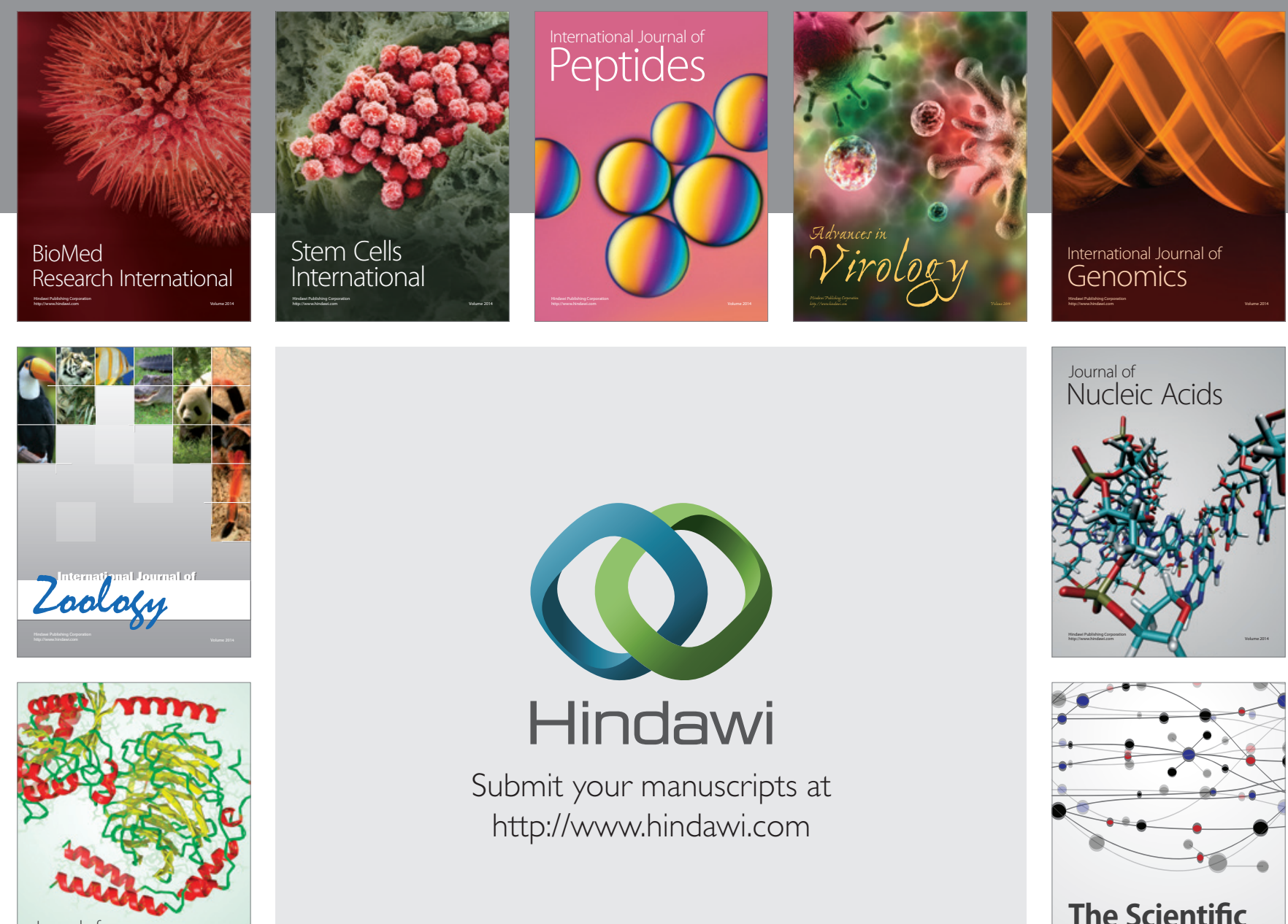

Submit your manuscripts at

http://www.hindawi.com

Journal of
Signal Transduction
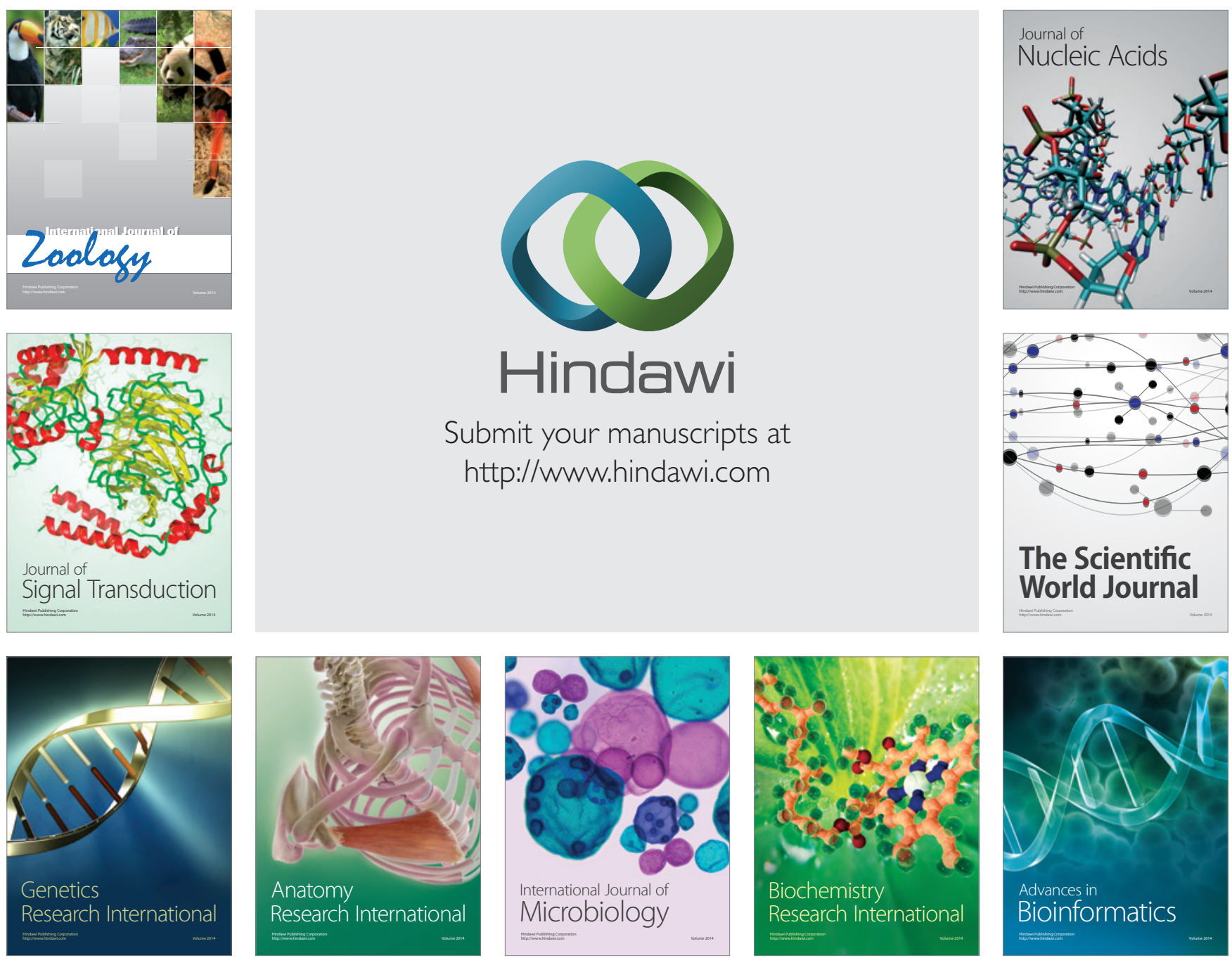

The Scientific World Journal
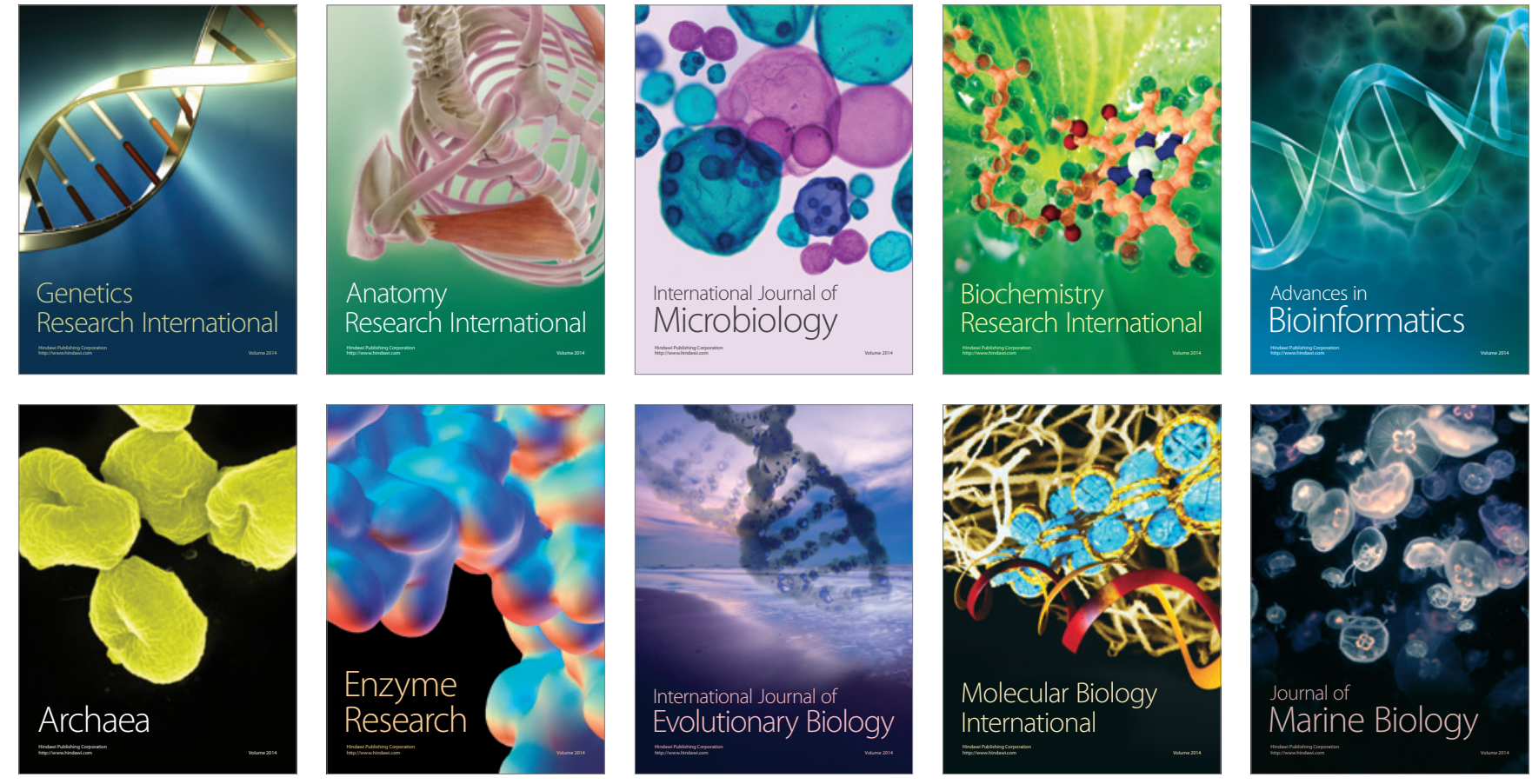